\title{
KAJIAN AKTIVITAS ANGGOTA KELOMPOK \\ DALAM PENGEMBANGAN LUMBUNG PANGAN \\ (Studi Kasus pada Kelompok Lumbung Pangan Jambesari di Desa Sidaharja \\ Kecamatan Pamarican Kabupaten Ciamis)
}

\author{
Oleh \\ FITRI YUROH \\ Fakultas Pertanian Universitas Galuh Ciamis \\ Email: fitriyuroh3@gmail.com
}

\begin{abstract}
Abstrak
Upaya memaksimalkan agar pencapaian Program Kelembagaan Lumbung Pangan tersebut berhasil, diperlukan adanya peningkatan kapasitas sumberdaya manusia, salah satu upaya tersebut melalui kegiatan pembinaan bagi Kelompok Lumbung Pangan. Dengan demikian pelaksanaan program tersebut diharapkan Kelompok Lumbung Pangan dapat menjadi kelembagaan ekonomi yang dimiliki dan dikelola petani. Penelitian ini bertujuan untuk mengetahui aktivitas anggota kelompok dalam pengembangan lumbung pangan. Metode yang digunakan dalam penelitian ini adalah metode studi kasus pada Kelompok Lumbung Pangan Jambesari di Desa Sidaharja Kecamatan Pamarican Kabupaten Ciamis, jumlah anggota 25 orang sebagai responden. Berdasarkan hasil penelitian diperoleh kesimpulan bahwa aktivitas Kelompok Lumbung Pangan berada pada kategori tinggi.
\end{abstract}

Kata kunci: lumbung pangan, ketahanan pangan

\section{PENDAHULUAN}

Pemenuhan kebutuhan pangan bagi setiap individu selalu mendapatkan prioritas perhatian masyarakat dunia, baik di negara maju maupun Negara berkembang. Perhatian atas pangan lebih mengemuka semenjak diadakannya World Food Summit yang pertama oleh FAO (Food and Agriculture Organization) pada tahun 1974, dengan pernyataan penting adalah "seluruh negara dan masyarakat dunia secara keseluruhan mengupayakan untuk menghilangkan kelaparan dan kekurangan gizi dalam waktu satu dekade". Sangat disayangkan pernyataan pada pertemuan FAO tersebut belum dapat diwujudkan dengan baik. Oleh karena itu pada World Food Summit yang diselenggarakan oleh FAO tahun 1996 memberi tekanan lebih besar mengenai pentingnya ketahanan pangan dengan dikeluarkannya kesepakatan "untuk mencapai ketahanan pangan bagi setiap orang dan untuk melanjutkan upaya menghilangkan kelaparan di seluruh negara (Suryana, 2003).

Program Pengembangan lumbung pangan masyarakat merupakan salah satu program yang bertujuan mengurangi kemiskinan. Berdasarkan data dari Badan Pusat Statistik (BPS) Provinsi Jawa Barat (2010) jumlah penduduk di Jawa Barat sekitar 43,1 juta jiwa, dari jumlah tersebut sebanyak 4.716 juta jiwa atau 10,93 persen berada pada katagori miskin, sedangkan tahun 2009 sekitar 42,0 juta jiwa, dari jumlah tersebut sebanyak 4.852 juta jiwa atau 11,57 persen penduduk miskin. Selama periode 2009-2010 telah terjadi menurunan kemiskinan sebabnyak 0,36 persen.

Permasalahan mendasar yang dihadapi petani adalah kurangnya akses kepada sumber permodalan, pasar, dan teknologi, serta organisasi tani (kelembagaan tani) yang masih lemah. Untuk itu, program Pengembangan lumbung pangan masyarakat sebagai upaya penanggulangan kemiskinan merupakan bagian dari pelaksanaan Rencana Pembangunan Jangka Panjang provinsi Jawa Barat dan berada dalam kelompok program pemberdayaan masyarakat.

Arifin (2005) menjelaskan bahwa Kelembagaan pangan merupakan salah satu komponen penting dalam menunjang kerangka dasar perumusan kebijakan pangan dan pembangunan pertanian untuk mencapai kesejahteraan masyarakat. kelembagaan menuju ketahanan pangan mengalami dinamika. Kelembagaan yang dimaksud disini adalah suatu aturan yang dikenal, dikuti dan ditegakkan secara baik oleh anggota masyarakat, yang memberi naungan dan hambatan (constraints) bagi individu atau anggota masyarakat. Kelembagaan memberi nafas dan ruang gerak bagi tumbuh dan berkembangnya suatu organisasi, yang sebenarnya memiliki ruh kehidupan karena sutau kelembagaan. 


\section{MIMBAR \\ A GRIBISNIS}

ISSN 2460-4321

Volume 1 • Nomor 1 • Juli 2015

Lumbung pangan adalah salah satu bentuk kelembagaan cadangan pangan yang dibentuk oleh masyarakat desa/kota atau pemerintah yang bertujuan untuk pengembangan penyediaan cadangan pangan bagi masyarakat di semua tingkat wilayah yang dikelola secara berkelompok. Kelompok Lumbung Pangan adalah lembaga yang dibentuk dan dikelola oleh masyarakat yang bergerak dalam pengembangan cadangan pangan meliputi bidang penyimpanan, pendistribusian, pengolahan, pengemasan, dan tataniaga bahan pangan (Pemerintah Provinsi Jawa Barat, Badan Ketahanan Pangan Daerah, 2013).

Upaya memaksimalkan agar pencapaian Program Kelembagaan Lumbung Pangan tersebut berhasil, diperlukan adanya peningkatan kapasitas sumberdaya manusia, salah satu upaya tersebut melalui kegiatan pembinaan bagi Kelompok Lumbung Pangan. Dengan demikian pelaksanaan program tersebut diharapkan Kelompok Lumbung Pangan dapat menjadi kelembagaan ekonomi yang dimiliki dan dikelola petani.

Pola dasar Kelembagaan Kelompok Lumbung Pangan yaitu mengembangkan usaha ekonomi produktif petani, pembinaan diperankan sebagai pendampingan dalam melaksanakan program tersebut sesuai dengan potensi usaha ekonomi produktif di perdesaan. Dengan demikian agar segala aktivitas sebagai pendampingan berjalan secara produktif, efektif, dan efisien, maka perlu didukung oleh pengurus dan seluruh anggota kelompok. Selain itu, partisipasi anggota dalam pengelolaan program merupakan indikator keberhasilan pelaksanaannya (Syahyuti, 2007).

Masalah ini akan menjadi titik awal dan mendorong untuk dilaksanakannya penelitian terkait pengembangan lumbung pangan, dalam hal ini apakah masyarakat siap bergabung dalam kegiatan Kelompok Lumbung Pangan dalam upaya mencapai Keberhasilan kegiatan pengembangan lumbung pangan di Kabupaten Ciamis. Penelitian ini bertujuan untuk mengetahui aktivitas anggota kelompok dalam pengembangan lumbung pangan.

\section{TINJAUAN PUSTAKA}

Lumbung pangan sering diartikan sebagai bangunan fisik tempat menyimpan bahan pangan maupun sebagai sentra penghasil pangan pada suatu wilayah. Namun demikian yang dimaksud dengan lumbung pangan dalam hal ini adalah sebagaimana yang dijelaskan dalam Surat Keputusan Menteri Dalam Negeri dan Otonomi Daerah No. 6 Tahun 2001 tentang Pengembangan Lumbung Pangan Masyarakat Desa/ Kelurahan yang bergerak di bidang penyimpanan, pengolahan, dan pemasaran bahan pangan yang dibentuk dan dikelola oleh masyarakat.

Kelembagaan lumbung pangan merupakan salah satu unsur pendukung ketahanan pangan yang perlu direvitalisasi agar mampu memberikan kontribusi yang lebih signifikan terhadap upaya mewujudkan kesejahteraan masyarakat melalui pemenuhan cadangan pangan dan kebutuhan sosial masyarakat yang dimulai dari skala rumah tangga sebagaimana yang diamanatkan dalam Undang-Undang No. 7 Tahun 1996 tentang pangan (Binangkitgapoktan, 2013).

Selanjutnya Binangkitgapoktan (2013) menyatakan bahwa kelompok Lumbung Pangan merupakan wujud suatu kelembagaan sosial ekonomi di pedesaan. Peran kelembagaan lumbung pangan selain berperan sebagai fungsi sosial dalam penyediaan cadangan pangan masyarakat diharapkan juga berperan sebagai fungsi ekonomi bagi kesejahteraan anggota dan masyarakat di sekitar desa sasaran.

Lebih lanjut Binangkitgapoktan (2013) menyatakan bahwa ktivitas Kelompok Lumbung Pangan dimaksudkan untuk :

a. Menumbuhkembangkan rasa bangga terhadap budaya lumbung desa (leuit).

b. Menumbuhkembangkan rasa peduli terhadap sesama yang tidak dapat mengakses pangan.

c. Mengimplementasikan rasa kesalehan sosial. Terhadap masyarakat miskin di lingkungannya.

d. Menjaga dan meningkatkan ketersediaan dan tersalurnya cadangan pangan daerah untuk penanganan pangan (kelebihan pangan, kekurangan pangan, ketidakmampuan mengakses pangan).

e. Meningkatkan pemanfaatan pangan lokal dalam rangka penciptaan permintaan untuk produk pangan lokal.

Salah satu faktor internal yang berpengaruh terhadap efektivitas (keberhasilan) Kelompok Lumbung adalah kepemimpinan ketua kelompok. Pada dasarnya pemimpin 
mempunyai peranan yang aktif dan senantiasa campur tangan dalam segala masalah yang berkenaan dengan kebutuhan-kebutuhan anggota kelompok. Yukl (2001) mendefinisikan kepemimpinan sebagai proses untuk mempengaruhi orang lain untuk memahami dan setuju dengan apa yang perlu dilakukan dan bagaimana aktivitas dilakukan secara efektif, serta proses untuk memfasilitasi upaya individu dan kolektif untuk mencapai tujuan bersama.

Efektivitas kepemimpinan berdasarkan konsekuensi dari tindakan pimpinan bagi pengikut dan komponen lain dalam organisasi. Berbagai jenis hasil yang digunakan mencakup aktivitas dan pertumbuhan kelompok/organisasi. Kesiapannya dalam menghadapi tantangan dan krisis, kepuasan para pengikut, komitmen anggota terhadap tujuan kelompok, kesejahteraan dalam perkembangan psikologis, bertambahnya status pemimpin dalam kelompok dan kemajuan pemimpin ke posisi wewenang yang lebih tinggi.

Yukl (2001) menyebutkan bahwa efektivitas kepemimpinan diukur berdasarkan kontribusi pemimpin pada kualitas proses kelompok yang dirasakan oleh anggota atau pengamat dari luar. Kemampuan pemimpin dalam peningkatan kohesivitas/keeratan anggota, kerjasama anggota, motivasi anggota, penyelesaian masalah, pengambilan keputusan dan mendamaikan konflik antar anggota.

Menurut Yukl (2001), kepemimpinan dapat dilihat dari dua aspek, yaitu (1) aspek status dan (2) aspek peranan. Kepemimpinan dari aspek status mempunyai arti penting sebagai teladan bagi warga-warga kelompok, diantaranya tempat bertanya, meminta nasihat dan saran-saran. Kepemimpinan dapat dilihat dari kemampuannya beramah tamah, menaruh perhatian angota-angotanya, membuat pilihan serta memperinci tugas-tugas dan melakukan pembagian kerja.

Kementerian

Pertanian

menyebutkan kepemimpinan ketua kelompok, paling tidak akan dilihat dari 3 (tiga) aspek, yaitu (1) kekuatan ketua kelompok dalam kelompok; (2) integritas ketua kelompok sebagai pemimpin kelompok; dan (3) pelaksanaan peran ketua kelompok dalam seluruh kegiatan kelompok khususnya dalam mengembangkan usaha produktif kelompok.
Tiap-tiap pemimpin sekurang-kurangnya memiliki tiga ciri antara lain :

1) Persepsi sosial, adalah kecakapan untuk cepat melihat dan memahami perasaan, sikap, dan kebutuhan anggota kelompok.

2) Kemampuan berpikir abstrak.

3) Kestabilan emosi (emotional stability). Pemimpin yang baik lebih banyak memiliki emosi yang stabil daripada mereka yang bukan pemimpin.

Kementerian Pertanian R.I (2010) mendefinisikan kemandirian sebagai kesadaran/kemampuan untuk mengembalikan keadaan ke normal setelah terjadinya suatu tekanan, gejolak dan bencana. Dalam keadaan normal, dimana tidak terjadi tekanan, bencana atau gejolak, maka kemandirian dapat diartikan sebagai kesadaran/kemampuan untuk meningkatkan keadaan masa depannya menjadi lebih baik tanpa bergantung pada orang lain. Berkaitan dengan kata mandiri, terkandung makna suatu kondisi dinamis untuk berbuat sesuatu tanpa tergantung atau menyandarkan diri pada kebaikan dan bantuan pihak lain, tetapi tidak menjadikan bantuan itu sebagai tumpuan hidupnya.

Menurut Soedijanto (2004), sikap mandiri meliputi kemandirian material, kemandirian intelektual dan kemandirian pembinaan. Kemandirian material, artinya mereka akan memiliki kapasitas untuk memanfaatkan secara optimal potensi sumberdaya alam yang mereka miliki sendiri tanpa harus menunggu bantuan orang lain atau tergantung dari luar; Kemandirian intelektual, artinya mereka akan memiliki kapasitas untuk mengkritisi dan mengemukan pendapat tanpa dibayangi rasa takut atau tekanan dari pihak lain; sedangkan kemandirian pembinaan, artinya mereka akan memiliki kapasitas untuk mengembangkan dirinya sendiri melalui proses pembelajaran tanpa harus tergantung atau menunggu sampai adanya pembina atau agen pembaharu dari luar sebagai guru mereka.

Badan Ketahanan Pangan Provinsi Jawa Barat (2008) menyebutkan indikator kemandirian dalam Program Aksi Desa Mandiri Pangan (proksi mapan) dilihat dari aspek pemberdayaan masyarakat dan pengembangan sistem ketahanan pangan.

Indikator kemandirian dalam pemberdayaan masyarakat dilihat dari (1) 


\section{AIMBAR \\ Agribisnis}

ISSN 2460-4321

Volume 1・Nomor 1・Juli 2015

efektifitas peran Tim Pangan Desa dalam pendampingan masyarakat dan pembangunan ketahanan pangan desa; (2) Perkembangan usaha-usaha produktif yang dikelola kelompok Lumbung Pangan dan masyarakat desa; (3) Keberadaan jaringan usaha dan pemasaran produk lokal dengan mitra usaha/koperasi/investor, dan lainnya; dan (4) Peran masyarakat dalam penyediaan dan distribusi pangan.

Indikator kemandirian dalam pengembangan sistem ketahanan pangan diukur dengan (1) Penyediaan dan distribusi pangan; (2) Kemampuan rumah tangga dalam mengakses pangan; (3) Perkembangan usaha produktif; (4) Pola konsumsi pangan 3B dan aman; (5) Penyelesaian masalah pangan wilayah; dan (6) Pelayanan masyarakat dalam: akses permodalan, kesehatan, dan sarana usaha. (Kementrian Pertanian,2010).

Menurut Undang-Undang No. 41 Tahun 2009, kemandirian pangan adalah kemampuan produksi pangan dalam negeri yang didukung kelembagaan ketahanan pangan yang mampu menjamin pemenuhan kebutuhan pangan yang cukup di tingkat rumah tangga, baik dalam jumlah, mutu, keamanan, maupun harga yang terjangkau, yang didukung oleh sumber-sumber pangan yang beragam sesuai dengan keragaman.

\section{METODE PENELITIAN}

Metode yang digunakan dalam penelitian ini adalah metode studi kasus pada Kelompok Lumbung Pangan Jambesari di Desa Sidaharja Kecamatan Pamarican Kabupaten Ciamis, jumlah anggota 25 orang sebagai responden.

Pengukuran nilai variabel merupakan hasil penjumlahan seluruh nilai indikatornya. Tingkat variabel Aktivitas Kelompok Lumbung Pangan diklasifikasikan seperti Tabel 1.

\section{Tabel 1. Klasifikasi dan Skor tiap Variabel}

\begin{tabular}{|c|c|c|}
\hline No. & Klasifikasi & Klasifikasi \\
\hline 1 & Rendah & $18,0-29,9$ \\
\hline 2 & Sedang & $30,0-41,9$ \\
\hline 3 & Tinggi & $42,0-54,0$ \\
\hline
\end{tabular}

\section{HASIL DAN PEMBAHASAN}

Hasil penelitian tentang aktivitas anggota kelompok dalam pengembangan lumbung pangan pada Kelompok Lumbung Pangan Jambesari terdiri dari aktivitas penyimpanan, pengolahan, pengemasan, pendistribusian, dan tataniaga bahan pangan. Selangkapnya mengenai aktivitas anggota kelompok dalam pengembangan lumbung pangan pada Kelompok Lumbung Pangan Jambesari dapat dilihat pada Tabel 2.

Tabel 2. Variabel Aktivitas Kelompok Lumbung Pangan

\begin{tabular}{|c|c|c|c|c|c|}
\hline No & Aktivitas & $\begin{array}{l}\text { Skor } \\
\text { Ideal }\end{array}$ & $\begin{array}{c}\text { Skor } \\
\text { Diperoleh }\end{array}$ & Kategori & $\begin{array}{l}\text { NT } \\
(\%)\end{array}$ \\
\hline 1 & Penyimpanan & 12 & 11,6 & Tinggi & 96,7 \\
\hline 2 & Pengolahan & 12 & 9,9 & Tinggi & 82,5 \\
\hline 3 & Pengemasan & 12 & 11,2 & Tinggi & 93,3 \\
\hline 4 & Pendistribusian & 9 & 8,5 & Tinggi & 94,4 \\
\hline 5 & Tataniaga bahan pangan & 9 & 7,9 & Tinggi & 87,8 \\
\hline & Jumlah skor & 54 & 49,1 & Tinggi & 90,9 \\
\hline
\end{tabular}

Tabel 2 menunjukkan bahwa aktivitas anggota Kelompok Lumbung Pangan Jambesari berada pada kategori tinggi dengan skor ratarata yang diperoleh sebesar 49,1 dari nilai harapan sebesar 54,0 dengan Nilai Tertimbang
90,9 persen. Persentase indikator dari variabel Aktivitas Kelompok Lumbung Pangan berada pada kategori tinggi yang berasal dari kelima indikatornya. 
Hasil penelitian menjelaskan, bahwa petani anggota Kelompok Lumbung Pangan Jambesari dalam melakukan usahanya berorientasi kepada pengembangan kegiatan usaha (ditunjukkan oleh indikator mulai dari penyimpanan, pengolahan, pengemasan yang memiliki kategori tinggi) dan berupaya untuk meningkatkan pendapatan bagi kebutuhan keluarga petani (ditunjukkan oleh indikator pendistribusian dan tataniaga bahan pangan yang memiliki kategori tinggi).

Berdasarkan Tabel 2 diketahui bahwa aktivitas anggota dalam pengolah memiliki nilai tertimbang sebesar 82,5 persen, nilai tertimbang dalam aktivitas pengolahan ini merupakan nilai tertimbang paling kecil dibandingkan indikator yang lainnya. Hal ini menunjukkan bahwa aktivitas anggota dalam pengolahan bahan pangan kurang maksimal. Anggota kelompok kurang menjaga kebersihan gabah, kurang menjaga hama dan penyakit dan kurang mengolah gabah menjadi beras serta kurang mengolah beras (berkualitas).

Berdasarkan wawancara dengan para petani anggota Kelompok Lumbung Pangan Jambesari, tujuan yang hendak dicapai kelompok dimaksud, yaitu :

1) Meningkatkan tanggungjawab petani dan pihak yang berkepentingan terhadap keberlanjutan fungsi dan manfaat sumberdaya Lumbung Pangan.

2) Menyelaraskan kegiatan pengelolaan sumberdaya lahan sawah dengan kegiatan pembangunan wilayah (Sektor pertanian tanaman pangan) sesuai dengan kondisi dan dinamika sosial masyarakat desa.

3) Meningkatkan mutu sumberdaya lahan sawah sesuai dengan karakteristik wilayah.

4) Meningkatkan pendapatan petani serta pihak yang berkepentingan (Lumbung Pangan) secara simultan.

Pencapaian tujuan tersebut tentunya akan menghendaki adanya tuntutan hak dan kewajiban dari masing-masing pihak (kelompok tani, gapoktan, lumbung pangan, dan petugas lapang). Adapun hak dan kewajiban dari petugas lapang antara lain: memfasilitasi kelompok tani dalam proses penyusunan rencana, monitoring, dan evaluasi; memberikan kontribusi faktor produksi; mempersiapkan sistem, struktur, dan budaya yang kondusif; serta bekerjasama dengan pihak yang berkepentingan (pasar dan pengusaha agribisnis gabah/beras) dalam rangka mendorong proses optimalisasi dan berkembangnya kegiatan, sedangkan hak dan kewajiban Kelompok Lumbung Pangan meliputi: menyusun rencana, melaksanakan monitoring, dan evaluasi secara bersama-sama anggota; mendapatkan manfaat dari hasil kegiatan usaha yang disesuaikan dengan nilai proporsi faktor produksi yang dikontribusikannya; serta memperoleh dukungan masyarakat desa dalam perlindungan sumberdaya lahan untuk keberlanjutan fungsi dan manfaatnya.

Petani anggota Kelompok Lumbung Pangan Jambesari menjelaskan lebih lanjut, bahwa kegiatan usaha mendasarkan pada prinsip kerja partisipatif, bukan top down approach, dibuat bersama dengan Dinas Pertanian Kabupaten Ciamis, serta disesuaikan dengan kebutuhan masing-masing anggota kelompoknya.

Umumnya faktor-faktor aktivitas Kelompok Lumbung Pangan Jambesari telah secara baik dilaksanakan (berkategori tinggi). Petani mampu mencari dan memilih informasi disebabkan oleh umur petani responden dalam usia produktif, mempunyai keberanian dalam mengambil risiko dalam mengadopsi inovasi teknologi, hubungan petani dengan petugas lapang baik dan kerap mengikuti pelatihan meski petani tidak sepenuhnya terbuka dalam mengungkapkan masalahnya kepada petugas lapang, sikap terhadap perubahan, motivasi berkarya bersifat inovatif, aspiratif.

Kelompok Lumbung Pangan di pedesaan yang diupayakan dalam rangka pemberdayaan kelompok, selama ini telah memotivasi petani anggota dalam memberi sesuatu sumbangan/kontribusi berupa keberadaan faktor-faktor sosial ekonomi yang dimilikinya untuk usaha mencapai tujuan kelompok yang sangat berarti, memanfaatkan kreativitas secara total dalam menyumbangkan pendapat dalam rapat-rapat anggota. Petani memiliki rasa tanggung-jawab dalam kegiatan usaha, keterlibatan mental dan emosionalnya yang sudah terpacu, terjadi pelibatan ego serta bukan hanya terlibat tugas yang bersifat keterlibatan secara jasmaniah, tetapi sebagai anggota memiliki rasa sense of belonging dengan 


\section{MIMBAR \\ A GRIBISNIS}

ISSN 2460-4321

Volume 1 • Nomor 1 • Juli 2015

keberadaan Kelompok Tani (Davis dan Newstrom, 1996).

Kegiatan kelompok bergantung pada keadaan sosial ekonomi petani dan berdampak pada adopsi inovasi dalam melaksanakan kerja kelompok yang didasarkan pada alasan dengan partisipasi lebih banyak hasil kerja yang dapat dicapai, pelayanan diberikan dengan biaya yang lebih efisien, di samping lebih menyadarkan petani akan pentingnya membangun masyarakat berdasarkan kekuatan sendiri (mandiri) (White, 1981) .

Koentjaraningrat (1988) menyatakan, bahwa aktivitas yang dimaksud adalah adopsi inovasi yang melibatkan masyarakat dengan melihat aspek-aspek sosial ekonominya dalam pembangunan sebenarnya menyangkut dua tipe yang pada prinsipnya berbeda, ialah a) adopsi inovasi diarahkan untuk aktivitas bersama dalam program pembangunan yang khusus, dan b) adopsi inovasi sebagai kegiatan individu di luar aktivitas bersama dalam pembangunan. Tipe pertama, seperti halnya kegiatan dimaksud, masyarakat pedesaan diajak dan dipersuasi oleh wakil dari dinas terkait atau pamong desa, untuk beraktivitas dan menyumbangkan tenaga atau hartanya kepada program pembangunan khusus tadi yang biasanya bersifat fisik. Tipe kedua tidak ada program bersama yang khusus tetapi ada program pembangunan, biasanya yang tidak bersifat fisik dan memerlukan peran serta masyarakat berdasarkan kemauan mereka sendiri.

Aktivitas kelompok lumbung pangan dilaksanakan berdasarkan metoda partisipatori, yakni merupakan cara untuk mengembangkan sumberdaya manusia (petani), agar mandiri dan mampu memecahkan permasalahan teknologinya sendiri. Menjadikan petugas lapang sebagai mitra kerja dalam mengembangkan kegiatannya yang dimulai dari perencanaan sampai kepada pelaksanaan kegiatan. Kelompok lumbung pangan merupakan wadah bagi petani untuk aktif menguasai dan mempraktikkan proses penciptaan ilmu pengetahuan atau secara khusus untuk meningkatkan aspek kemampuan, pengalaman, dan kemandirian petani dalam merencanakan dan melaksanakan teknologi yang bersifat spesifik lokalita.
Petani anggota mengemukakan, bahwa kemampuan mengelola lumbung pangan berawal dari upaya pembinaan dan pelayanan (fasilitas) yang diberikan oleh Petugas Lapang Dinas Pertanian Kabupaten Ciamis kepada Kelompok lumbung pangan. Kegiatan ini tercermin dalam kegiatan memberikan informasi, sarana produksi (cadangan pangan), informasi pasar, dan pengembangan usaha.

Petugas Lapang bertindak pula sebagai motivator, yakni menggugah perhatian anggota, membangkitkan keinginan, keyakinan, dan menggerakkan anggota kelompok untuk melakukan aktivitas lumbung pangan.

Dinas Pertanian pun bertindak sebagai dinamisator tercermin dari upayanya berinteraksi dengan anggota kelompok, membangun terjadinya interaksi antar anggota dan melibatkan semua anggota dalam setiap proses pengembangan lumbung pangan.

Bahasan di atas sejalan dengan pendapat Arintadisastra (2001), bahwa beberapa faktor yang mempengaruhi aktivitas petani, yakni : (1) Adanya interest, hadiah, keuntungan dari kegiatan, dan motivasi dari luar (motivator), (2) menyadari bahwa kegiatan yang dilakukan bermanfaat, (3) sesuai dengan kemauan dan kemampuannya, (4) mudah dicoba dengan hambatan yang tidak berarti, dan (5) dapat diterapkan secara berkelanjutan dan lingkungan hidup terjaga.

Sebaliknya, penghambat aktivitas petani meliputi : (1) kurang adanya komunikasi yang dapat menyebarluaskan informasi tentang pembangunan dari pemerintah sebagai tugas kepada masyarakat, rendahnya tingkat pendidikan dan pengetahuan masyarakat yang menyebabkan kurang kemampuan masyarakat untuk berpartisipasi dalam menerima dan menyebarluaskan informasi mengenai pembangunan, demikian pula dalam hal perencanaan, pelaksanaan, pengawasan, dan pemanfaatan hasil pembangunan, (2) Kemiskinan dan rendahnya penghasilan masyarakat yang memakan waktu dan tenaga untuk berpartisipasi dalam kegiatan pembangunan, (3) Sikap sosial yang terbentuk dan membudaya seperti paternalistic dan feodalisme menyebabkan warga masyarakat selalu pasrah dan senantiasa siap sedia dengan apa-apa yang dikemukakan oleh pemerintahan desa sehingga partisipasi yang bersifat langsung 


\section{FITRI YUROH}

dan terancam menjadi berkurang, dan (4) Belum jelasnya tujuan dan manfaat dari kegiatan pembangunan bagi masyarakat, sehingga masyarakat tidak tahu dan kurang memahami tujuan dan manfaat pembangunan tersebut (Arintadisastra,2001).

Pelembagaan aktivitas dalam pengembangan kelompok lumbung pangan sebagai upaya untuk meningkatkan produktivitas lahan sawah dan kelestarian lingkungan di masa datang (Purnawan, 2005). Sumintaredja (2001) menyatakan, bahwa partisipasi petani dalam aktivitas tersebut, adalah hasil dari proses belajar dan bekerja yang sistematik, berkelanjutan, dan terprogram dalam sistem interaksi antara petani dengan aparatur pemerintah (petugas lapang) sebagai fasilitator atau pemandunya dan bertindak selaku mitra.

Prinsip pendekatan pada dasarnya disesuaikan dan dikembangkan untuk kegiatan perencanaan, pengorganisasian, dan penerapan kegiatan baru, yang menempatkan petani sebagai pusat pengembangan masa depan. Hal ini ditunjukkan dengan indikator-indikator yang berada dalam klasifikasi tinggi (berhasil dalam pengembangan lumbung pangan). Secara umum kelompok lumbung pangan telah melakukan aktivitas sebuah organisasi sosial kemasyarakatan, khususnya mengayomi dan mengakomodasi seluruh kepentingan anggota masyarakat dalam melaksanakan dan mengelola kegiatan usaha lumbung pangan. Kekuatan kelompok tercermin dari praktik di lapangan yang menjadikan kelompok sebagai tempat bertanya, tempat meminta nasehat, dan tempat meminta saran-saran. Integritas kelompok tercermin dari perilaku kelompok menjaga konsistensi kebijakan yang telah diambil dengan aplikasinya dan rasa memiliki terhadap kelompok dibanding dengan kepentingan individualnya.

\section{PENUTUP}

Berdasarkan hasil penelitian dan pembahasan dapat diajukan simpulan bahwa Aktivitas Kelompok Lumbung Pangan Jambesari berada pada kategori tinggi dengan skor rata-rata yang diperoleh sebesar 49,1 dari nilai harapan sebesar 54,0 dengan Nilai Tertimbang 90,9 persen. Persentase indikator dari variabel Aktivitas Kelompok Lumbung
Pangan berada pada kategori tinggi yang berasal dari kelima indikatornya (ditunjukkan oleh indikator penyimpanan, pengolahan, pengemasan yang memiliki kategori tinggi) serta berupaya untuk meningkatkan pendapatan bagi kebutuhan keluarga petani (ditunjukkan oleh indikator pendistribusian dan tataniaga bahan pangan yang memiliki kategori tinggi).

\section{DAFTAR PUSTAKA}

Arifin, B., 2005. Ekonomi Kelembagaan Pangan. LP3ES. Jakarta

Badan Pelaksana Penyuluhan Pertanian, Perikanan, Kehutanan, dan Ketahanan Pangan Kabupaten Ciamis. 2013. Juknis Pengembangan Lumbung Pangan Desa Tahun 2014. Ciamis.

BPS Provinsi Jawa Barat. 2010. Statistik Indonesia. Badan Pusat Statistik. Jakarta.

Davis, J. dan Newstrom K. 2005. Pendidikan Pertanian untuk Petani. Jurnal Eksistensia Volume 3 Tahun II Februari 2005. Pusat Penyuluhan Departemen Pertanian, Jakarta.

Djoni. 2008. Metodologi Penelitian Sosial Ekonomi. Kasus Kelembagaan Kelompok Tani Pelaku Usahatani Terpadu di Jawa Barat (Kajian Perspektif Sosiologis). Program Pascasarjana Program Studi Ekonomi Pertanian Universitas Siliwangi Tasikmalaya.

Hamijoyo, S., 1978. Kepemimpinan Adopsi lnovasi untuk Pembangunan Masyarakat. Fak. Pertanian Unila. Lampung.

Kedi Suradisastra. 2008. Strategi Pemberdayaan Kelembagaan Petani. Pusat Analisa Sosial Ekonomi dan Kebijakan Pertanian. Bogor. Jurnal Forum Penelitian Agro Ekonomi, Volume 26 No 2 Desember 2008.

Kementerian Pertanian R.I. 2010. Pedoman Penumbuhan, Pengembangan Kelompoktani, dan Kelembagaan Petani. Jakarta.

Koentjaraningrat. 1988. Masyarakat Desa di Indonesia Masa Ini. BPFE UI. Jakarta.

Mosher, AT. 1985. Getting Agriculture Moving. Disandur oleh Krisnandhi, S dan Bahrin Samat. Menggerakkan dan Membangun Pertanian. CV. Jasaguna, Jakarta.

Mubyarto. 1989. Pengantar Ekonomi Pertanian, Penerbit Lembaga Penelitian, 


\section{AIMBAR \\ Agribisnis \\ ISSN 2460-4321}

Volume $1 ・$ Nomor $1 ・$ Juli 2015

Pendidikan dan Penerangan Ekonomi dan

Sosial (LP3ES), Jakarta.

Pemerintah Provinsi Jawa Barat, Badan

Ketahanan Pangan Daerah. 2013. Juklak

Lumbung Pangan Masyarakat (LPM)

Provinsi Jawa Barat APBD Tahun 2013.

Bandung.

Soekartawi. 1988. Prinsip Dasar Dasar Ekonomi Pertanian. PT. Grafindo Persada, Jakarta.

Sugiyono. 2004. Metode Penelitian Kuantitatif, Kualitatif dan $R \& D$. CV. Alfabeta. Bandung.

Soehardjo. A. dan Dahlan Patong. 1984. Sendisendi Ilmu Usahatani. LEPNAS. Ujung Pandang.

Suryana, A., 2003. Kapita Selekta : Evolusi Pemikiran Kebijakan KetahananPangan, Edisi 2003/2004, BPFE-YOGYAKARTA, Yogyakarta

Syahyuti. 2007. Kebijakan Pengembangan Gabungan Kelompok Tani (GAPOKTAN) Sebagai Kelembagaan Ekonomi di Pedesaan. Pusat Penelitian Sosial Ekonomi. Bogor.

Undang-Undang Nomor 6 Tahun 2014 tentang Desa. Setneg RI. Jakarta

White, A. 1981. Sekolah Lapangan untuk Pemberdayaan Petani Kecil. Field Indonesia, Jakarta.

Yukl, Gary. 2001. Kepemimpinan dalam Organisasi (terj), Prenrtice Hall, Inc. New jersey. 